\title{
Effects of Defatted Soy Flour Incorporation on Physical, Sensorial and Nutritional Properties of Biscuits
}

\author{
Aleem Zaker MD ${ }^{1 *}$, Genitha $\mathrm{TR}^{1}$ and Syed Imran Hashmi ${ }^{2}$
}

${ }^{1}$ Department of Food Process Engineering, Sam Higginbottom Institute of Agriculture Technology and Sciences, Allahabad 211007 (UP), India ${ }^{2}$ Department of Food Trade and Business Management, College of Food Technology, Marathwada Agricultural University, Parbhani 431402 (MS), India

\begin{abstract}
The study was conducted to standardize the levels of defatted soy flour in composite flour for biscuit preparation The defatted soy flour was incorporated in the traditional recipe to replace wheat flour at levels defatted soy flour by $0,10,20$, and 30 percent in preparation of biscuits. Sugar was replaced by the Stevia and Date paste while traditional shortening was replaced by Olive oil. The prepared biscuits were evaluated for its physical, sensorial and nutritional properties. Result of sensory (appearance, color, flavor, texture, taste, and overall acceptability) evaluation of biscuits showed that $20 \%$ addition of defatted soy flour had higher overall acceptability, taste, texture and flavor. The nutritional value of the biscuit as determined through nutrient analysis-moisture (2.7), Protein (13.53), Fat (17.74), ash (1.75), and total energy (462.30) with 20 percent of defatted soy flour was comparable to control (wheat flour) biscuit.
\end{abstract}

\section{Introduction}

The population everywhere desires to eat a healthier diet without changing their conventional dietary patterns [1]. Eating of healthy food has received more attention in the recent years due to disliking of some having some health concerns such as fat, sugar and salt [2].

Cereal based food products are part of stable diet of global population, where wheat is leading cereal crop and principally used in bakery products due to its much appreciated rheological characteristics. However, wheat protein is deficient in some indispensible essential amino acids [3,4]. Composite flour technology for wheat supplementation with protein rich materials like soybean could be an approach to overcome the malnutrition. The growth of bakery industry is about $10 \%$ per annum and the products are increasingly becoming popular among all sections of people [5]. Biscuits possess several attractive features including wider consumption base, relatively long shelf-life, more convenience and good eating quality [6,7]. Good eating quality makes biscuits attractive for protein fortification and other nutritional improvements. Biscuits are predominantly based on refined wheat flour (RWF) and the blending of RWF with oilseed such as soybean can upgrade the nutritional quality.

India is the largest producer of medicinal herbs and is called as botanical garden of the world [8]. Indian herbs are renowned all over the world for their medicinal properties. Many medicinal herbs are also food, oil and fibre plants and have always been grown for a range of purposes [9].

Present dietary scenario necessitates exploring the possibility of incorporating novel ingredients in commonly consumed foods rather than developing new food product. With the current status nutritional quality of biscuits and growing demand of nutritious foods, it seems worthwhile to take efforts in enhancing the nutritional value of biscuit. Soybean flour powder has recognized its utility as a base ingredient in preparing composite flour for bakery products. Therefore, in present investigation, efforts were made to standardize level of defatted soy flour in preparation of biscuits on the basis of physical, sensorial and nutritional quality characteristics.

\section{Materials and Methods}

The special research work on "Studies on effect of defatted soy flour incorporation on physical, sensorial and nutritional quality of biscuits" was carried out at Regional Food Research Analysis Center, Lucknow (UP) India during academic year 2010-2011.

\section{Materials}

Refined wheat flour, defatted soy flour (60 mesh sieved), shortening, baking powder, milk powder, salt, flavors, and other general ingredients were procured from the local market of Lucknow (UP) India.

\section{Methods}

Recipe for biscuits: In order to justify the use of biscuits as a health product, date palm paste and stevia leaves powder were used as a source of sweetness instead of using sugar which purely provides calories only. While, as a shortening, instead of using vegetable based hydrogenated fat, Olive oil was preferred. The date palm paste, stevia leave powder and olive oil based optimized and standardized recipe used in preparation of biscuits is summarized as follows

\section{Standardized Recipe for biscuits preparation}

\begin{tabular}{|c|c|c|c|c|}
\hline Composite flour & : & $100 \mathrm{~g}$ & Milk powder & $10 \mathrm{~g}$ \\
\hline Water & & $20 \mathrm{ml}$ & Olive oil & $10 \mathrm{ml}$ \\
\hline Date palm paste & : & $10 \mathrm{~g}$ & Stevia leaves powder & $0.25 \mathrm{~g}$ \\
\hline Baking powder & : & $1 \mathrm{~g}$ & & \\
\hline
\end{tabular}

Process of biscuit manufacturing: Ingredient was used for preparation of biscuits according to above stated recipe. Sieve the refined wheat flour and other dry ingredients and were mixed together

*Corresponding author: Aleem Zaker Md, Department of Food Process Engineering, Sam Higginbottom Institute of Agriculture Technology and Sciences, Allahabad 211007 (UP), India; Tel: +91-9890250652; E-mail: aleem.foodtech@yahoo.com

Received December 12, 2011; Accepted March 17, 2012; Published March 19 2012

Citation: Aleem Zaker MD, Genitha TR, Hashmi SI (2012) Effects of Defatted Soy Flour Incorporation on Physical, Sensorial and Nutritional Properties of Biscuits. J Food Process Technol 3:149. doi:10.4172/2157-7110.1000149

Copyright: (C) 2012 Aleem Zaker MD, et al. This is an open-access article distributed under the terms of the Creative Commons Attribution License, which permits unrestricted use, distribution, and reproduction in any medium, provided the original author and source are credited. 
to obtain a uniform blend. Olive oil, date palm paste and stevia leaves powder was mixed together to obtain sweetened shortening cream. Then slowly mixed dry flour was added to shortening cream with addition of water to prepare dough. The dough was prepared by manual kneading of all the dry and liquid ingredients to attain uniformity with desirable visco-elastic characteristics. When dough was ready it was kept for 10-15 minutes as it is and then used for sheeting, sheets were made by rolling balls of dough on wooden platform. These sheets were cut by hand operated metal dye, arranged on olive oil coated tray and were kept for baking. Baking takes place in three successive stages in electric oven. In the beginning structural changes take place due to heating of dough. In second stage greatest loss of moisture take place. In third stage the color of biscuit changes to typical light brown color of finished biscuit. Each lot requires $25-30$ minutes at $160^{\circ} \mathrm{C}$ for baking. The flow sheet for preparation of biscuits is described as follows (Chart $1)$ :

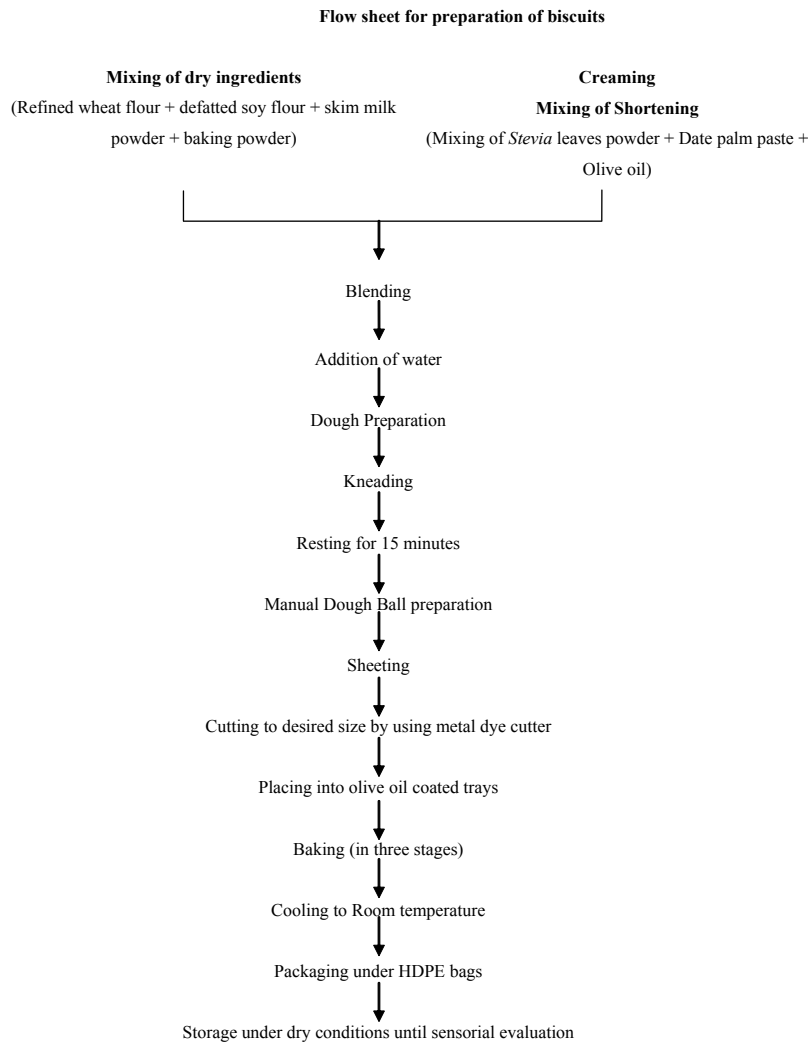

Formulation of composite flour for biscuit preparation: Preliminary experimental work was done with different high levels of Defatted Soy Flour (DSF) incorporation so as to select the range of per cent incorporation which could be used in formulating composite flour for biscuits. Through trial and error, coupled with continued informal sensory evaluation by a panel of food scientists, as a result of preliminary trials, it was found that not more than $30 \%$ of DSF could be used in preparation of composite flour as further increase in DSF concentration resulted in drastic reduction of overall acceptability of product. Further systematic studies have been carried out by considering following composite flour formulation for biscuit preparations.

$\mathrm{T}_{0}$ - Refined wheat flour (RWF) without incorporation of defatted soy flour (DSF)

$\mathrm{T}_{1}-10 \%$ replacement of RWF with DSF

\section{$\mathrm{T}_{2}-20 \%$ replacement of RWF with DSF}

$\mathrm{T}_{3}-30 \%$ replacement of RWF with DSF

\section{Physical analysis}

Diameter and thickness was measured using vernier caliper, while spread ratio was calculated as a ratio of diameter to thickness of biscuits.

\section{Analysis of raw material}

Gluten content of wheat flour was determined by washing off starch by standard procedure [10]. Estimation of moisture, ash, crude protein and fat content was also done by standard operating procedure [10].

\section{Organoleptic quality of biscuits}

The sensory evaluation of prepared herbal biscuits was carried out by a 25 member trained panel comprising of postgraduate students and academic staff members of faculty who had some previous experience in sensory evaluation of bakery products. The panel members were requested in measuring the terms identifying sensory characteristics and in use of the score. Judgments were made through rating products on a 9 point Hedonic Scale with corresponding descriptive terms ranging from 9 'like extremely' to 1 'dislike extremely'.

\section{Results and Discussion}

\section{Composition of wheat flour and defatted soy flour}

Composition of refined wheat flour and soy flour were determined to signify its suitability in preparation of biscuits. The obtained results are summarized in Table 1.

The refined wheat flour contained 11.87 per cent of crude protein while 8.72 per cent of gluten content was observed. The other results with respect to moisture, fat, ash and total carbohydrate were found to be $13.20,1.38,0.53$ and 68.17 per cent, respectively. The obtained results for the proximate composition and gluten content of wheat flour were similar to that of earlier reported results [11].

The results pertaining to composition of defatted soy flour revealed that it is rich in protein content i.e. 62.73 per cent, which justifies its utilization as a novel ingredient in nutritional food preparations. The moisture content was found to be 8.64 per cent which signifies its shelf life and storage. The 0.79 per cent fat remained in defatted soy flour described the superior efficiency of oil extraction process, while the 6.43 per cent of total ash reveals high mineral content. The shortening was replaced by olive oil. When baking (at high temperature) the nutritional value of olive oil may not decrease but it causes lipid peroxidation. Scaccini et al. [12] stated that a significantly lower concentration $(1.5+/-0.3 \mathrm{nmol} / \mathrm{ml})$ of thiobarbituric acid -reactive substances (TBA-RS) was found in olive oil, after exposing to higher temperature. However this value is within the recommended limit as per Codex Standard, 2001 for olive oil, which are 10 milli equivalent

\begin{tabular}{|c|c|c|c|}
\hline Sr. No. & Parameters & $\begin{array}{c}\text { Refined wheat } \\
\text { flour }\end{array}$ & Defatted soy flour \\
\hline 1 & Moisture (\%) & 13.20 & 8.64 \\
\hline 2 & Crude Protein (\%) & 11.87 & 62.73 \\
\hline 3 & Crude Fat (\%) & 1.38 & 0.79 \\
\hline 4 & Total Ash (\%) & 0.53 & 6.43 \\
\hline 5 & Total Carbohydrates (\%) & 68.17 & 21.18 \\
\hline 6 & Gluten content (\%) & 8.72 & -- \\
\hline
\end{tabular}

*Each value is average of 3 determinations

Table 1: Physico-chemical properties of refined wheat flour and soy flour. 
peroxide/kg oil. The obtained results with respect to composition of defatted soy flour represent the high nutritional profile which could result in nutritional enhancement incorporated biscuits.

\section{Physical parameters of composite flour based biscuits}

The physical parameters of biscuits are commonly used parameter in objective judgment of quality. The data related to effect of different levels of defatted soy flour incorporation on physical properties of prepared biscuits is summarized in Table 2 .

The results revealed that increase in level of DSF incorporation results in linear decrease of total weight, diameter, spread ratio and hardness. While, thickness of biscuits increased with increase in concentration, reduction of spread ration of biscuits may be attributed to better binding strength of soy protein, also resulting in increase of thickness. The DSF incorporated biscuits reported to have lower hardness. This could be attributed to high water binding capacity of defatted soy flour.

\section{Standardization of composite flour for biscuit preparation}

The study was carried out to understand the influence of blend ratio (refined wheat flour: defatted soy flour), upon the textural attributes (viz. crispness, cutting strength, hardness) and Overall acceptability of biscuits. Preliminary experimental work was done with a different high level of Defatted Soy Flour (DSF) incorporation so as to select the range of per cent incorporation which could be used in formulating composite flour for biscuits. Numerous practice attempts were made. Through trial and error, coupled with continued informal sensory evaluation by a panel of food scientists, as a result of preliminary trials, it was found that not more than $30 \%$ of DSF could be used in preparation of composite flour as further increase in DSF concentration resulted in drastic reduction of overall acceptability of product. Further systematic studies have been carried out so as to design an optimum formulation of composite flour and then the prepared biscuits were analyzed for its physico-chemical parameters, sensorial characteristics, and nutritional properties of composite flour based biscuits.

Optimization of DSF incorporation in preparation of composite flour for biscuits was also majorly based on the sensorial quality characteristics. The obtained results with respect to sensorial quality of DSF biscuits is summarized in Figure 1.

The data depicted in Figure 1 revealed that incorporation of DSF has marked improvement in colour, appearance and textural profile of prepared biscuits up to concentration of 20 per cent while further increase in concentration results in drastic reduction in appearance, color, flavour, texture as well as taste characteristics.

With respect to appearance, it was observed that incorporated of DSF results in grainy appearance of biscuits which were preferred by panellist members up to 20 per cent while in case of 30 per cent DSF incorporated biscuits, excessive grainy appearance secured lower values.

The colour characteristics of biscuits showed to be darker with increase in concentration of DSF which enhanced consumer appeal up to 20 per cent of incorporation. Similar trend to that of flavour scores was observed in case of colour values of incorporated biscuits.

Textural profile plays an important role in justifying the overall acceptability of biscuits, here in case of DSF incorporated biscuits, slight improvement in crispiness of biscuits were observed in samples up to 20 per cent of DSF, hence secured better scores while in case of biscuits containing 30 per cent of soy flour, the panellists reported dryness of mouth hence secured least scores.

The overall acceptability of composite flour based biscuits was determined by taking average of all the values pertaining to appearance, colour, flavour, texture and taste. It was found that sample $\mathrm{T}_{2}$ containing 20 per cent of DSF found to secure maximum score (8.37) followed by $\mathrm{T}_{1}(8.28)$ and control (8.23) while least overall acceptability was observed in $\mathrm{T}_{3}$ sample containing 30 per cent of defatted soy flour.

On the basis of overall acceptability of biscuits, it could be concluded that incorporation of defatted soy flour in preparing composite flour up to the level of 20 per cent is superior to all other treatments and control sample and hence 20 per cent DSF incorporation in preparation of composite flour for biscuits could considered optimum with respect to sensorial quality characteristics.

\section{Proximate composition of composite flour based biscuits}

As stated earlier, the prime objective of defatted soy flour incorporation in preparation of composite flour for biscuit was to enhance its nutritional value. Hence, during present investigation, biscuits prepared with different concentration of defatted soy flour were analyzed for its proximate composition and the obtained results are given in Table 3.

It could be seen from the Table 3 that increase in concentration of DSF in biscuits has significant effect on its proximate composition. The moisture content of biscuits increased linearly with increase in concentration of DSF, this may be attributed to high water binding

\begin{tabular}{|c|c|c|c|c|}
\hline Sample & Weight $(\mathbf{g})$ & Diameter $(\mathbf{m m})$ & Thickness (mm) & Spread Ratio \\
\hline Standard (A) & 10 & 63 & 6.3 & 10.33 \\
\hline B & 9.5 & 62 & 6.5 & 9.38 \\
\hline C & 9.5 & 61 & 7.0 & 26 \\
\hline D & 9.2 & 60.5 & 7.3 & 26 \\
\hline
\end{tabular}

Table 2: Physical parameters of biscuits prepared from different levels of defatted soy flour.

\begin{tabular}{|c|c|c|c|c|c|c|c|}
\hline Sample & Moisture (\%) & Ash (\%) & Fat (\%) & Protein (\%) & Crude fiber (\%) & Carbo-hydrate (\%) & Energy (Kcal) \\
\hline Standard (A) & 2.4 & 0.69 & 17.98 & 5.76 & 0.12 & 71.23 \\
\hline B & 2.6 & 1.50 & 17.87 & 10.55 & 0.5 & 65.92 \\
\hline C & 2.7 & 1.75 & 17.74 & 13.53 & 469.78 & 0.7 & 62.13 \\
\hline D & 3.2 & 2.10 & 17.63 & 15.73 & 0.8 & 46.71 \\
\hline
\end{tabular}

* Each value is average of 3 determinations

Table 3: Proximate composition of defatted soy flour based biscuits. 


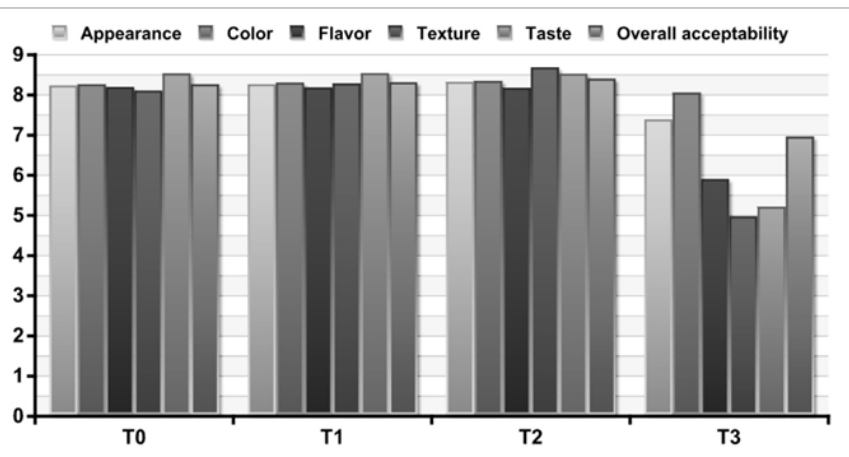

Figure 1: Sensory evaluation of biscuit prepared from composite flour.

capacity of DSF which is retaining higher moisture content in ultimate product. The ash content of biscuits is also significantly increased due to higher ash content of DSF. The total fat content of biscuits is majorly a function of externally added fat during biscuits preparation. Both refined wheat flour and defatted soy flour were having lower fat content and hence the total fat content of sample retaining more or less similar while there was slight reduction in fat content with increase in defatted soy flour incorporation.

Estimation of protein content of sample showed high improvement in nutritional value of DSF incorporated biscuits with maximum value of 15.73 per cent in 30 per cent DSF based biscuits, compared to that of control sample containing merely 5.76 per cent of protein. Many studies have showed that heat liable browning of baked products containing higher protein may contribute to the poor ability to digest protein. The result pertaining to protein content justifies the suitability of defatted soy flour incorporation in making of composition for nutritional enhancement of biscuits.

The total carbohydrate content of biscuits found to decrease linearly with increase in DSF concentration. The variations are due to lower carbohydrate content of defatted soy flour. The total calorific value of control samples was observed to be higher $(469.78 \mathrm{Kcal})$ compared to DSF incorporated biscuits ( $461.63 \mathrm{Kcal})$; however, it is worthwhile noting that major source of calories in case of treated samples was contributed by protein which is superior in terms of nutrition point of view.

On the basis of proximate analysis of prepared biscuits, it could be concluded that defatted soy flour incorporation increased the nutritional status of biscuits due to high protein content.

\section{Summary and Conclusion}

In the present investigation sincere efforts were made to enhance the nutritional quality of biscuits by incorporating defatted soy flour. The results pertaining to composition of refined wheat flour and defatted soy flour showed the suitability as a base ingredient in biscuits preparation.

The results pertaining to standardization of composite flour for biscuit preparation revealed that sensorial quality characteristics of biscuits could be improved with incorporation of 20 per cent of defatted soy flour in refined wheat flour in formulating composite flour for biscuits preparation. On the basis of overall acceptability of biscuits, it could be concluded that 20 per cent DSF incorporation in preparation of composite flour for biscuits could be considered optimum with respect to sensorial quality characteristics while the physical parameters of composite flour based biscuits were also observed to be superior. 20 per cent incorporation of defatted soy flour enhances the protein content of biscuits (13.53 per cent). On the basis of proximate analysis of prepared biscuits, it could be concluded that defatted soy flour incorporation increased the nutritional status of biscuits due to high protein content.

\section{Conclusion}

On the basis of obtained results, it could be concluded that defatted soy flour incorporation up to the level of 20 per cent in formulating composite flour for biscuits preparations enhanced the overall acceptability and physical quality characteristics of biscuits while different herbs viz. Brahmi, lemongrass, shilajit, makoi, badiyan, kasni could be utilized successfully in preparation of herbal biscuits at the level of $0.5 \mathrm{~g}, 0.5 \mathrm{~g}, 0.5 \mathrm{~g}, 5 \mathrm{ml}, 10 \mathrm{ml}$ and $5 \mathrm{ml}$, respectively.

\section{References}

1. Becker CC, Kyle DJ (1998) Developing functional foods containing Alga Docosahexaenoic acid. Food Technol 52: 68-71.

2. Hilliam M (1995) The market for healthy and functional confectionery. The World of Ingredients 8-9.

3. Chastain TG, Ward KJ, Wysocki DJ (1994) Stand establishment responses of soft white wheat to seedbed residue and seed size. Crop Sci 35: 213-218.

4. Carlson JB, Lersten NR, Athow KL, Boerma HR, Coble HD et al. (1987) Reproductive morphology. In: Soybeans: Improvement, Production, and Uses. $\left(2^{\text {nd }}\right.$ Edn) Wilcox JR, American Society of Agronomy, Madison, Wisconsin 95134.

5. Indrani D, Savithri GD, Venkateswara Rao G (1997) Effect of defatted soy flour on the quality of buns. J Food Sci Technol 34: 440-442

6. Tsen CC, Peters EM, Schaffer T, Hoover WJ (1973) High protein cookies Effect of soy fortification and surfactants. Bakers Digest 47: 34-37.

7. Hooda S, Jood S (2005) Organoleptic and nutritional evaluation of whea biscuits supplemented with untreated and treated fenugreek flour. Food Chem 90: 427-435

8. Grover JK, Yadav S, Vats V (2002) Medicinal plants of India with antidiabetic potential. J Ethnopharmacol 81: 81-100.

9. Parry JW (1969) Spices Volumes I \& II. Chemical Publishing Co, New York.

10. AOAC (1975) Official Methods of Analysis. Association of Agricultural Chemists. Washington DC.

11. Gopalan C, Rama Sastri BV, Balasubramanian SC (2004) Nutritive value of Indian Foods. National Institute of Nutrition Press, Indian Council of Medical Research, Hyderabad (AP) India.

12. Scaccini C, Nardini M, D’Aquino M, Gentili V, Di Felice M, et al. (1992) Effect of dietary oils on lipid peroxidation and on antioxidant parameters of rat plasma and lipoprotein fractions. J Lipid Res 33: 627-633. 